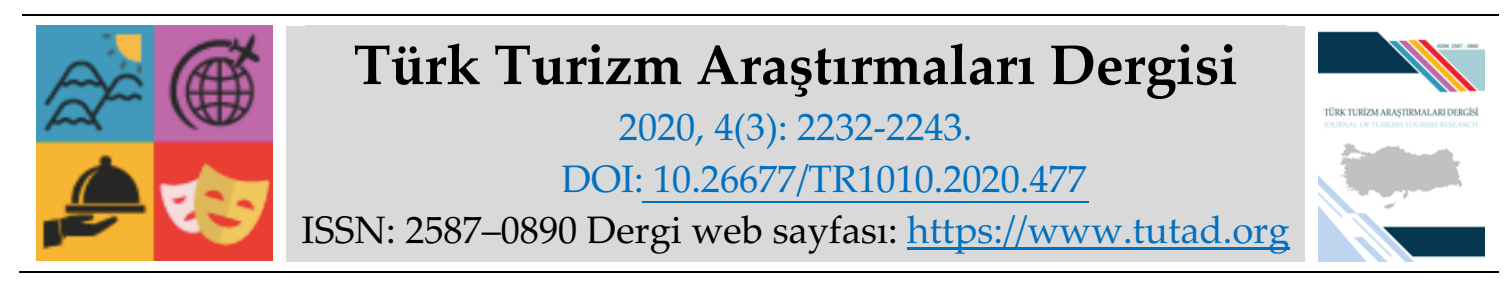

ARASTIRMA MAKALESI

\title{
Audio-Guide Kullanımı: Dolmabahçe Sarayı Örneği
}

Dr. Öğr. Üyesi Seçkin ESER, Kırklareli Üniversitesi, Turizm Fakültesi, Kırklareli, e-posta: seckineser@outlook.com

ORCID: https://orcid.org/0000-0001-9972-5818

Zafer ERLER, Bilim Uzmanı, Kırklareli Üniversitesi, Sosyal Bilimler Enstitüsü, Kırklareli, e-posta: zafererler39@gmail.com

ORCID: https://orcid.org/0000-0003-2401-1831

Öz

Müze ve ören yerlerinde sıkça kullanılmaya başlayan teknolojik uygulamalardan biri "audioguide (sesli rehber)" uygulamasıdır. Bu çalışma turist rehberlerinin Dolmabahçe Sarayı'nda kullanılan audio-guide teknolojisi hakkında düşüncelerini belirlemeye yönelik yapılmıştır. Müze, ören yeri, saray ve köşk gibi tarihi ve turistik mekânlarda kullanılan audio-guide teknolojisi hakkında bilgi verilecek ve bu teknolojinin turu, turistleri ve turist-rehber ilişkilerini nasıl etkileyeceği, etkin bir gezi için neler yapılabileceği ortaya konmuştur. Çalışma verileri 2019 yılı Haziran ayında 23 turist rehberinden görüşme formu yaklaşımıyla toplanmıştır. Veriler içerik analizine tabi tutulmuştur. Turist rehberlerinin büyük bir çoğunluğunun, Dolmabahçe Sarayı'nda uygulanan audio-guide uygulamasına dönük olumsuz bir tutum sergiledikleri, turist rehberliği hizmetini engelleyici bir unsur olarak gördükleri belirlenmiştir. Audio-guide teknolojisinin etkin bir gezi için gerekli durumlarda tamamlayıcı bir destek aracı olarak kullanılması gerektiği önerisi ile son bulmaktadır.

Anahtar Kelimeler: Audio-guide, Dolmabahçe Sarayı, Teknoloji, Turist Rehberi.

Makale Gönderme Tarihi: 25.03.2020

Makale Kabul Tarihi: 01.07.2020

\section{Önerilen Atıf:}

Eser, S. ve Erler, Z. (2020). Audio-Guide Kullanımı: Dolmabahçe Sarayı Örneği, Türk Turizm Araştırmaları Dergisi, 4(3): 2232-2243.

(C) 2020 Türk Turizm Araştırmaları Dergisi. 


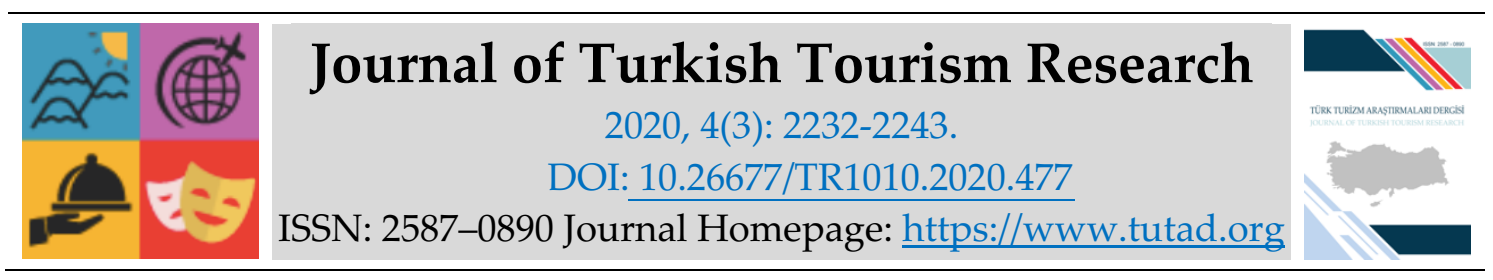

\title{
RESEARCH PAPER
}

\section{Audio Guide Usage: Case of Dolmabahce Palace}

Assistant Prof. Dr. Seçkin ESER, Kırklareli University, Faculty of Tourism, Kırklareli, e-mail: seckineser@outlook.com

ORCID: https://orcid.org/0000-0001-9972-5818

Zafer ERLER, MSc., Kırklareli University, Social Sciences Institute, Kırklareli, e-mail: zafererler39@gmail.com

ORCID: https://orcid.org/0000-0003-2401-1831

\begin{abstract}
One of the technological applications that are frequently used in museums and ruins is the "audio-guide" application. This study was carried out to determine the opinions of the tourist guides about the audio-guide technology used in Dolmabahce Palace. In the study, information will be given about the audio-guide technology used in historical and touristic places such as museums, ruins, palaces and mansions. In addition, it will be revealed how this technology will affect the tour, tourists and tourist-guide relationships, what can be done for an effective trip. The study data were collected from 23 tourist guides in June 2019 using the interview form approach. The data were subjected to content analysis. It has been determined that the vast majority of tourist guides exhibit a negative attitude towards the audio-guide application implemented in Dolmabahce Palace, and they see this application an obstacle factor in tourist guidance service. It ends with the suggestion that audio-guide technology should be used as a complementary support tool for an effective trip.
\end{abstract}

Keywords: Audio-guide, Dolmabahce Palace, Technology, Tourist Guide.

Received: 25.03 .2020

Accepted: 01.07.2020

\section{Suggested Citation:}

Eser, S. and Erler, Z. (2020). Audio Guide Usage: Case of Dolmabahce Palace, Journal of Turkish Tourism Research, 4(3): 2232-2243.

(C) 2020 Türk Turizm Araştırmaları Dergisi. 


\section{Gíriş}

Günümüz dünyasında her geçen gün teknolojik gelişmelerin sayısı ve niteliği artmaktadır. Yaşanan teknolojik değişimler ve yenilik hareketleri insanların hayatını kolaylaştırmak, daha hızlı hizmet, daha iyi ürün anlayışı amacıyla yapılmaktadır (Tekin vd., 2017:291-292). Teknolojik gelişmeler ve yenilikler, turizm sektörünü de etkilemiştir. İnsan yaşamında yer alan seyahat ve turizm kavramı teknolojiye bağlı olarak gelişim göstermeye başlamıştır (Bjorneseth, 2005:13). Bu gelişmeler, turizm ürünlerinde ve tur süreçlerinde etkilerini göstermektedir.

Turistler, tercih ettikleri destinasyonların kültürel, tarihi vb. alanlarını ziyaret etme eğilimindedirler. Bu ziyaretlerinde turistlere daha önce gitmediği, bilmediği, deneyim yaşamadığı yerler hakkında bilgi veren, yönlendiren turist rehberleri eşlik etmektedir (Köroğlu, 2013:93-94). Turist rehberleri, turizm sektörü içerisinde yalnızca turistlerle iletişim halinde olmayan, sektör içerisinde yer alan kurum ve kuruluşlarla, yerel halk ile de iletişim halinde olan bu sebeple köprü görevi gören anahtar role sahip bireylerdir. Turist rehberleri, turistlerin ziyaret ettiği turistik bölgeleri anlamaları için öğretici role sahip, turistlerin tekrar ziyaretlerini etkileyen ve misafirperver kişilerdir (Eser, 2018:25). Turist rehberleri, turların içeriğine göre tura hazırlanırken veya tur sırasında çeşitli teknolojik aletlerden yararlanmaktadırlar (Büyükşalvarcı vd., 2017:2). Teknolojik destek araçlarından yararlanma isteğindeki asıl amaç ise rehberlerin turistlere unutulmaz tatil deneyimleri yaşatmak ve tur esnasında işlerini yürütebilmektir (Çolakoğlu vd., 2017:172).

Müzelerde, bu gelişmeler doğrultusunda teknolojiyle uyumlu olarak gelişim göstermeye ve teknolojik uygulamaları benimsemeye başlamışlardır (Özel, 2016:177). Hemen hemen her alanda kullanılmaya başlayan teknoloji temelli ürün ve uygulamalar, müze ve ören yerlerinde de son yıllarda sıkça kullanılır duruma gelmiştir (Çapar ve Karamustafa, 2018:206). Müzeler, sadece eser koleksiyonları olan merkezler olmaktan uzaklaşarak değişmeye başlamıştır (Ceserio vd., 2017:2). Müzelerde kullanılan canlandırma teknolojileri, 3D animasyon ve görüntü teknolojileri, artırılmış gerçeklik teknolojisi, sanal asistan, gibi farklı çeşitte teknolojik yenilikler kullanılmaktadır (Tekin vd., 2017:294-295). Ayrıca bazı ören yerlerinde, turistler taşınabilir ses oynatıcıları (audio-guide) kiralayabilmektedirler. Bu durumda, ziyaretçiler rehbere ihtiyaç duymadan müzeleri ve ören yerlerini ziyaret edebilmektedirler (Eser vd., 2019:2). Müzeleri turist rehberi eşliğinde gezmek fark yaratsa da (Sarsılmaz, 2010:2), günümüz teknolojisinin hızlı ilerleyişi, rehberlik hizmetinin sadece turist rehberlerinin anlatımına bağlı olarak değil, teknolojik aletler yardımıyla da yapılabildiğini göstermektedir (Tekin vd., 2017:294-295). Bu durum da teknolojik aletlerin turist rehberinin verdiği hizmeti kısmen de olsa yerine getirmekte olduğu ve rehberlik hizmetini tehdit edici unsurlar olarak algılanabileceği söylenebilir.

Araştırma, turist rehberlerinin Dolmabahçe Sarayı'nda kullanılan audio-guide teknolojisi hakkında düşüncelerini ortaya koymaya yönelik tasarlanmıştır ve audio-guide teknolojisi hakkında bilgilendirme yapılmaktadır. Turist rehberlerinin bakış açısıyla turistlerin audio-guide kullanımına dönük beğeni ya da eleştirilerinin ortaya konarak, audio-guide teknolojisinin rehberturist ilişkisi üzerindeki etkisinin değerlendirilerek, etkin bir gezi için neler yapılabileceği ortaya konmaktadır. Ayrıca turizm sektöründe, müzelerde, ören yerlerinde, saray ve köşk gibi tarihi ve turistik mekânlarda kullanılan audio-guide teknolojisinin özellikleri, avantajları ve dezavantajları ortaya konarak alanyazına katkıda bulunulmak istenmektedir.

\section{TURIZM ve TEKNOLOJI}

Teknoloji, endüstriler arasında çok hızlı değişim ve gelişim göstermektedir (Khatri, 2019:75). 1950 yılından sonra hızlı bir ivme kazanımıyla, turizm alanında gelişim göstermeye başlamıştır. 
Turizm sektörünün, teknoloji uygulamalarının doğal olarak farklı dönemlerde gelişme kaydettiği bilinmektedir. Öncelikle, örgüt yapılarında değişim yaşanmamış ve ulaşım alanında teknolojiler tercih edilmiştir. Devamında, bilgisayar rezervasyon sistemleri ve küresel dağıtım sistemleri kullanılmaya başlanmıştır. Üçüncü dönemde, turizm sektörü küresel ölçekte eğilim göstermiş, yeni bilgi iletişim teknolojileri dâhil edilmiştir. Son süreçte ise yeni bilgi teknolojileri gelişmiş, internet gibi araçlar kullanılmış ve kullanılmaya devam etmektedir (Ünüvar, 2008:607-608).

Turizm sektörü de teknoloji uygulamalarının desteği ile daha hızlı gelişen sektörlerden biridir. Dolayısıyla, modern teknolojilerin gelişmesi, turizm pazarı ve turizm taleplerini de hızlı bir şekilde değişime uğratmıştır (Khatri, 2019:75). 20. yüzyılın ikinci yarısında hızla gelişen ileri teknolojilerle birlikte bilgi toplumu oluşmuştur. İşletmelerin ve kurumların küresel pazarda rekabet edebilmeleri için büyük oranda yeni gelişmelere uyum sağlamaları gerekliliği ortaya çımıştır (Yolal, 2003:8). Böylece değişen ve gelişen teknolojiye ayak uydurabilen, teknolojik gelişimleri takip eden ve hizmetlerini bu yönde farklılaştıran turizm işletmeleri ayakta kalabilmekte ve fark yaratabilmektedir (Durna ve Babür, 2011:74).

Bilgi ve iletişim teknolojileri, turizm endüstrisini önemli ölçüde etkisi altına almış ve turizmde yeniliklerin ana itici güç kaynağı olmuş ve olmaya devam etmektedir (Devices, 2015:224). Buhalis ve Law (2008), teknolojik ilerleme ve turizm uygulamalarının yıllardır birlikte gelişim gösterdiğini ve değişikliklerin yaşandığını belirtmektedir. Dünyada yaşanan teknolojik gelişmeler, turizm işletmelerinin müşteri ihtiyaçlarını daha iyi anlamasına ve bu doğrultuda gelişim göstermelerine yardımcı olmuştur. Bilgi ve iletişim teknolojilerinin desteği ile yeni pazarlara girme, maliyetleri düşürme ve dağıtımlar kanallarına ulaşım hızı artmıştır. E-turizm, e-pazarlama, bilgisayar rezervasyon sistemleri, sesli turlar, uçuş paketleri, mobil teknolojiler vb. uygulamalar turizm sektöründe yaşanan teknolojik gelişmelerin sonuçları olarak ortaya çıkmaktadır (Wahab, 2017:260).

Ayrıca teknolojide yaşanan gelişimler, turizm sektöründe, yeniliklerden uygulamalara giden mobil ve web uygulamalarına doğru değişim geçirmiştir (Khatri, 2019:75). Teknoloji gelişimi ile ortaya çıkan mobil uygulamalar turizm sektöründe müşteriler ile bağlantı kurmak için vazgeçilmez bir ortam olarak kabul görmektedir. Bu teknolojiler, seyahat ve turizm endüstrisi için önemli görülmekte, müşterilerin uçuş rezervasyonları, konaklama rezervasyonları vb. işlemlerini güvence altına almasına yardımcı olmaktadır (Stram vd., 2014:1001). Collins ve Cobanoglu (2008) teknolojinin gelişmesi ile konaklama işletmelerinde kullanılan teknolojilerde de büyük bir gelişme yaşandığı ve konaklama işletmelerindeki temel unsurun müşterilere evinden uzak olsa da en az evlerinde sahip oldukları konforu ve kullanmaya alışık oldukları teknolojileri sağlamak olduğunu belirtmiştir.

Dolayısıyla, turizm endüstrisi teknolojik gelişim ve değişimlere bağlı gerçekleşen uygulamaları kullanmaktadır. Turizm sektöründe kullanılan birçok teknoloji uygulamalarının avantajları olduğu kadar, dezavantajları da olabilmektedir. Özellikle, turizm sektöründe çalışan kişilerin olumlu veya olumsuz olarak teknoloji uygulamalarından etkilendiği düşünülmektedir (Yüksek, 2013:18).

\section{TURIST REHBERİ ve AUDIO-GUIDE TEKNOLOJISİ}

Turizm sektörü açısından önemli bir meslek grubu kabul edilen rehberlik mesleği de teknolojik gelişmelerden olumlu veya olumsuz şekillerde etkilenmektedir. Bu gelişmelerden biri olan audio-guide teknolojisidir. Audio-guide teknolojisi, turistlerin gezdiği yerler hakkında bilgi veren bir sistemdir. Sesli rehber sistemi olarak açılanmaktadır. Sesli rehber sistemi, Kültür ve Turizm Bakanlığı' na bağlı müze/ören yerine gelen ziyaretçilere sunulmaktadır. Müzede sunulan 
eserler hakkında grup turları için radyo frekansı ile çalışan seyyar mikrofon ve kulaklık düzeneği bulunan, ziyaret edilen mekân hakkında bilgi edinilmesini sağlanmaya dönük olarak geliştirilen ve kullanılan teknolojik uygulamadır (dosim.kulturturizm.gov.tr). Belirli ücret karşıllğında özellikle müze ve ören yerlerinde kullanılabilen, taşınabilir özelliği bulunan teyp kayıtlarıdır (Ahipaşaoğlu, 2006:118).

Audio-guide teknolojisinin müzelerde kullanımı ve ilk denemeleri, 1930-1960 yılları arasındaki dönemde $A B D$ ve Hollanda başta olmak üzere yeni bir kültürel arabuluculuk eğilimine yönelen ülkelerde yapılmıştır. Audio-guide teknolojisi ziyaretçi tarafından taşınabilen, cep telefonuyla benzer donanımlardır. Bu teknoloji ziyaretçilere müze, oda ve diğer eserler hakkında yorum ve açıklamaların yanı sıra kavrayışlarına da yardımcı olmaktadır (Martins, 2012:104).

Audio-guide teknolojileri, elektronik rehberlik uygulamaları arasında en çok tercih edilen cihazlardır. Ayrıca müze, kongre ve sergi gibi birçok alanda kullanılmakta birçok şirket tarafından üretimi ve gelişimi sağlamakta olan modelleri vardır (Harmankaya, 2010:16). Audioguide teknolojisi, Türkiye'de Kültür ve Turizm Bakanlığı'na bağlı 14 müze ve ören yerinde toplamda 22 alanda faaliyettedir. Tablo 1'de gösterilmektedir.

Tablo 1.Türkiye'de Kültür ve Turizm Bakanlığı'na bağlı Audio-Guide Teknolojisi Kullanılan Müze ve Ören Yerleri

\begin{tabular}{|l|l|}
\hline \multicolumn{2}{|c|}{ Audio-Guide Kullanılan Müze ve Ören Yerleri } \\
\hline 1-Antalya Arkeoloji Müzesi (Antalya) & 12-Aydın Millet Ören Yeri (Aydın) \\
\hline 2- Myra Ören Yeri (Antalya) & 13- Aydın Didim Ören Yeri (Aydın) \\
\hline 3- Aziz(s.t) Nikolaos Anıt Müzesi (Antalya) & 14- Gaziantep Zeugma Müzesi (Gaziantep) \\
\hline 4- Kariye Müzesi (İstanbul) & 15- Galata Mevlevihanesi (İstanbul) \\
\hline 5- Bodrum Sualtı Arkeoloji Müzesi (Muğla) & 16- Hacıbektaş Müzesi (Nevşehir) \\
\hline 6- İzmir Arkeoloji Müzesi (İzmir) & 17- Zeugma Mozaik Müzesi (Gaziantep) \\
\hline 7- Efes Ören Yeri (İzmir) & 18- Anadolu Medeniyetleri Müzesi (Ankara) \\
\hline 8- Bergama Akropol Ören Yeri (İzmir) & 19- Ayasofya Müzesi (İstanbul) \\
\hline 9- Troia Ören Yeri (Çanakkale) & 20- Mevlana Müzesi (Konya) \\
\hline 10- Laodikeia Antik Kenti (Denizli) & 21- Göreme Açı Hava Müzesi (Nevşehir) \\
\hline 11- Afrodisias Müzesi ve Ören Yeri (Aydın) & 22- Topkapı Sarayı (İstanbul) \\
\hline
\end{tabular}

Kaynak: dosim.kulturturizm.gov.tr

Audio-guide teknolojisi şu şekilde gerçekleşmektedir. Müze ve Ören yerleri içerisinde bazı eserlerin yanında bir numara yazılmaktadır. Cihaza o numara yazıldığı zaman cihaz eser hakkında bilgi vererek genel mekânlar ve genel tarih konularında anlatım yapabilmektedir. Kesin ve kontrollü bilgiyi aktaran, istenilen dilde anlatım yapabilen, bireysel olarak gezi süresini ayarlayabilme fırsatı sağlayan araçlardır. Buna karşılık tek düze açılamaların sunulduğu aletlerdir. Audio-guide araçlarına soru sorma imkânı yoktur ve canlandırma yetisine sahip değillerdir; her turistin bilgi düzeyi eşit olmadığı için eksik bilgi birikimi oluşmaktadır. Özellikle konuşma dili turistten turiste değiştiği için anlaşılmazlık yaratabilmektedir (Ahipaşaoğlu, 2006:118). Müzelerin audio-guide teknolojisi ile mekana bağlı olarak yapılan anlatıları mantıklı ve tutarlı bir şekilde mevcut olsa da tüm müze ziyaretçileri uygulamayı takip etmeyi, öğrenmeyi ve etkileşime geçmeyi tercih edemeyebilir (Ceserio vd., 2017: 2).

Dolmabahçe Sarayı TBMM Milli Saraylara bağlı bir tarihi mekândır. Milli Saraylar Gezi Yönetmeliği'nin beşinci maddesinin birinci fıkrası "Milli Sarayların ziyarete açık birimleri Elektronik Rehberlik Sistemi ve/veya rehber eşliğinde gezilir. Milli Saraylarda, Müzecilik ve Tanıtım Başkanlığınca belirlenecek esaslara göre randevu sistemi uygulanır" şeklindedir (www.millisaraylar.gov.tr). Ayrıca, TBMM Milli Saraylar'dan alınan yazıda; TBMM Milli 
Saraylara bağlı saray, köşk, kasır ve müzelerde Ekim 2017 itibariyle audio-guide sistemine geçiş yapılmıştır. Bu sistem Dolmabahçe Sarayı'nda 17 dilde hizmet vermektedir. Dolmabahçe Sarayı'nda 2 Mart 2018 itibariyle rehberli grupların sesli anlatım yapamayacağı, bunun yerine audio-guide veya headset (mikrofon) teknolojilerinin kullanılmasının gerekli olduğu bildirilmiştir (iro.org.tr). Bu durumda Dolmabahçe Sarayı'nda audio-guide sistemi zorunludur.

Dolmabahçe Sarayı'nda sesli anlatım yapılmamaktadır. Sarayı ziyaret eden turist gruplarının rehberi dilerse headset (mikrofon) teknolojisini kullanarak anlatım yapabilir veya turist rehberi grubu için audio-guide teknolojisini kullanabilmektedir. Turist rehberleri headset (mikrofon) teknolojisini kendileri getirebilir veya gişeden ayrı bir ücret ödemeden temin edebilmektedir. Sarayda kullanılan teknolojileri (audio-guide ve headset) turist grupları için turist rehberleri, gruptaki kişi sayısına bağlı olarak, kendi kimliği karşılığında teslim almakta ve gezi sonunda bırakmaktadır. Bireysel ziyaret eden turistlerin audio-guide teknolojisi kullanmaları zorunludur. Çok nadir olsa da gruptaki kişi sayısı 5 'ten az olduğu takdirde, turist rehberinin sessiz şekilde anlatım yapmasına izin verilebilmektedir.

Mevcut literatür incelendiğinde teknolojik uygulamalar açısından, turist rehberlerinin bakış açısını belirlemeye yönelik az sayıda da olsa çalışmaya (Çakmak ve Demirkol, 2017; Yıldız, S. 2018; Eser vd., 2019) rastlanmaktadır. Ancak audio-guide teknolojisini rehberlerin gözüyle inceleyen bir çalışmaya rastlanmamıştır. Çakmak ve Demirkol, (2017) turist rehberlerinin turlarda teknolojiden çok kez yararlandıklarını araştırmalarında belirtmişlerdir. Çakmak ve Demirkol, (2017) turizmin her bir dalında etkili olan teknolojinin rehberlik mesleğinin icrası içinde öneminin artacağı sonucuna varmıştır. Turist rehberlerinin müze ve ören yerlerinde gpsnavigasyon teknolojisi, akıllı telefonlar, ulaşım sistemleri, headset (mikrofon) gibi teknolojiler kullandığı zaman ziyaretçiler üzerinde olumlu yönde iz bıraktığını ortaya çıarmışlardır. Yıldız (2018) teknolojik rehber olarak adlandırılan audio-guide, headset, play guide, mobil rehber, interaktif multimedya tur rehberi, guide port, robot turist rehberleri gibi teknolojileri turist rehberlerinin bakış açısıyla incelemiştir. Çalışmada, turist rehberlerinin çoğunluğu, teknolojik rehberlik hizmetlerinin profesyonel rehberlik hizmetini azalttığını belirtmiştir. Katılımcıların birçoğunun teknolojik rehberlik aletlerini mesleki tehdit olarak görmediği ifade edilmiştir. Ayrıca çalışma kapsamında turist rehberleri teknolojik rehberlerin performansının yetersiz olduğunu ifade etmiştir. Teknolojik rehber olarak nitelendirilen araçlara olumlu yönde ve olumsuz yönde bakan turist rehber sayıları eşit olarak belirlenmiştir. Eser vd., (2019) turist rehberlerinin turlarda, teknolojiden yararlandıklarını ama bunları belirli sınırlar içerisinde kullandıklarını belirtmiştir. Turist rehberlerinin mikrofon sistemi, tablet kullanımını olumlu bulduklarını, müzelerde kullanılan arkeolojik kazı, interaktif inceleme uygulamalarının heyecan uyandırdığını ve faydalı bulduklarını ancak audio-guide teknolojisine sıcak bakmadıklarını belirtmişlerdir. Ayrıca, turist rehberlerinin turlarda teknolojik uygulamaları destek amacıyla yardımcı birer unsur olarak kullandıklarını belirlemişlerdir.

\section{ARAŞTIRMANIN AMACI}

Çalışmanın amacı, turist rehberlerinin Dolmabahçe Sarayı'nda kullanılan audio-guide teknolojisi hakkında düşüncelerini belirlemektir. Bu sayede müze, ören yerleri, saray ve köşk gibi tarihi ve turistik mekânlarda kullanılan audio-guide teknolojisinin turu, turistleri, turist-rehber ilişkisini nasıl etkilediği ortaya konmaktadır. Çalışma, turist rehberlerinin bakış açısıyla turistlerin audioguide teknolojisine dönük olumlu ya da olumsuz eleştirileri hakkında bilgi edinmek, rehberturist ilişkisi üzerindeki etkisinin değerlendirilmesi açısından önemlidir. Turist rehberi ve turist ilişkisinin düzeyi, turistin turdan memnuniyet düzeyini etkileyebilecek ve dolayısıyla tatmin düzeyi artabilecektir. Turist ve rehber ilişkisinde iletişim ne kadar etkili olursa, turistlerin 
algıladığı hizmet kalitesinin olumlu etkiler bırakması mümkündür. Ayrıca turist rehberlerinin gözüyle etkin bir gezi için Dolmabahçe Sarayı'nda ve diğer müzelerde neler yapılması gerektiğiyle ilgili önerilerde bulunulacaktır.

\section{YÖNTEM}

Keşifsel bir yöntem ile hareket edilen çalışmada veriler görüşme yoluyla toplanmıştır. Bu sebeple görüşme formu hazırlanmıştır. Görüşme formunda araştırma kapsamına yönelik sorular ve turist rehberlerinin demografik özelliklerini içeren sorular yer almıştır. Görüşme soruları alanyazını taraması neticesinde, turist rehberi- turist ve kullanılan teknolojik uygulamalar dikkate alınarak hazırlanmıştır. Araştırma kapsamında turist rehberlerine, audio-guide teknolojisine dönük görüşleri, turistlerin audio-guide teknolojisi hakkında nasıl değerlendirmeler yaptığını, audioguide teknolojisinin rehber-turist ilişkisi üzerine olan etkisini ve Dolmabahçe Sarayı'nda etkili bir gezi için neler yapılabileceğine dönük açı uçlu sorular yöneltilmiştir.

Görüşmeler 23 turist rehberi ile Dolmabahçe Sarayı'nda ve çevresinde 2019 Haziran ayında yüz yüze görüşme tekniği kullanılarak yapılmıştır. Nitel veri toplama çalışmalarında örneklem büyüklüğünün 15 olması tavsiye edilmektedir (Mason, 2010:8). Dolayısıyla, örneklem büyüklüğünün yeterli olduğu söylenebilir. Çalışmanın evrenini aktif turist rehberleri oluşturmaktadır. Araştırmanın örneklemini ise 2019 Haziran ayında Dolmabahçe Sarayı'nı rehberlik mesleğini aktif yürüten turist rehberleri oluşturmaktadır. Görüşmeler kapsamında turist rehberlerine; Dolmabahçe Sarayı'nda audio-guide teknolojisi ile ilgili görüşlerinin ortaya konması amaçlanmıştır. Görüşmeden elde edilen veriler betimsel analiz yapılmıştır.

\section{BULGULAR}

Turist rehberlerinin Dolmabahçe Sarayı'nda audio-guide kullanımına ilişkin görüşlerini değerlendirmeye yönelik olarak 23 turist rehberi ile görüşülmüştür. Turist rehberlerinin $11^{\prime}$ i 10 yıl ve üzeri, 8'i 6-9 yıl; 4'ü ise 3-5 yıl arası sektörde hizmet verdiğini ifade etmiştir. Turist rehberlerinden $4^{\prime}$ ü seyahat acentesine bağlı olarak, 19'u serbest olarak çalışmaktadırlar. Turist rehberlerinin 8'i ön lisans, 8'i lisans, 7'si ise Kültür ve Turizm Bakanlığının kurslarından çalışma kartlarını aldıklarını ifade etmişlerdir. Turist rehberlerinin çalışma kartlarında yazan yabancı dil değerlendirmelerinde 17'sinin İngilizce, 5'inin Rusça, 3'ünün Almanca, 4'ünün Çince, 3'ünün Lehçe, 2'sinin İtalyanca, 1'inin Japonca, Portekizce, Fransızca olduğu belirtilmiştir. Çalışma kartlarında birden fazla yabancı dil bulunan turist rehberleri yer almaktadır. Katılımcıların demografik özellikleri aşağıda Tablo 2' de belirtilmiştir.

Tablo 2. Katılımcıların Demografik Özellikleri

\begin{tabular}{|l|c|l|c|}
\hline \multicolumn{2}{|c|}{ Turist Rehberlerinin Çalışma Süresi } & \multicolumn{2}{c|}{$\begin{array}{c}\text { Turist Rehberlerinin Çalışma Kartlarında } \\
\text { Yazan Diller }\end{array}$} \\
\hline 10 yıl ve üzeri & 11 & İngilizce* & 17 \\
\hline 6-9 yıl & 8 & Rusça* & 5 \\
\hline 3-5yıl & 4 & Almanca* & 3 \\
\hline \multicolumn{2}{|c|}{ Turist Rehberlerinin Eğitim Durumu } & Çince & 2 \\
\hline Ön Lisans Rehberlik & 8 & İtalyanca & 1 \\
\hline Lisans Rehberlik & 8 & Japonca & 1 \\
\hline KTB Sertifika Programı & 7 & Portekizce & 1 \\
\hline Turist Rehberlerinin Çalışma Şekli & Fransizca & 3 \\
\hline Acenteye bağlı & 4 & Lehçe & \\
\hline Serbest & 19 & & \\
\hline
\end{tabular}

*Birden fazla yabancı dil yeterlilikleri bulunmaktadır. 


\section{Dolmabahçe Sarayı'nda Audio-Guide Teknolojisine Dönük Rehber Görüşleri}

Turist rehberleri genel olarak audio-guide teknolojisine sıcak bakmadıklarını ifade etmişlerdir. Turist rehberlerinden 19'u audio-guide teknolojisinin rehberin hizmet alanına girdiğini, bu teknolojinin zaten rehberin asli görevi olduğunu ifade etmişlerdir. Turistlerle birebir ilişki düzeyini kısıtladığını, bilgi konusunda yetersiz olduğunu ve rehberin grubun üzerindeki etkisini azalttığını belirtmişlerdir. Rehberlerin büyük çoğunluğu, cihazların teslim alma ve teslim verme sürecinde çok uzun beklenildiği ve zaman kaybı yarattı̆̆ını, uygulama sırasında soruları yanıtlama durumunun olamamasının olumsuz bir durum olduğunu dile getirmişlerdir. Duygu katılamayan bir turun turizm alanında bir anlam ifade etmediğini vurgulamışlardır. 3 turist rehberi dil sayısı bakımından audio-guide teknolojisinin yetersiz olduğunu, Polonyalı gruplar geldiği zaman "Lehçe" dilinde anlatımın bulunmamasının sıkıntı yarattığını belirtilmişlerdir. 3 turist rehberi, gezi esnasında bu teknolojiyi kullandıkları ve grupla birlikte katılım gösterdikleri takdirde, içeride soru sormalarının yasak olduğunu belirtmişlerdir. Buna karşın 2 turist rehberi ise yukarıda belirtilen olumsuz yönlere rağmen turistlerin serbestçe gezebildiği ve yoğunluk durumlarında hızlı gezi imkânı sağlayabildiğini ve ses kirliliğini önlemeye yönelik bir teknoloji olduğunu ifade etmişlerdir.

\section{Dolmabahçe Sarayı'nda Audio-Guide Teknolojisine Dönük Turist Rehberlerinin Bakış Açısıyla Turistlerin Görüşleri}

Turist rehberlerinin büyük bir çoğunluğu, turistlerin bu teknolojiyi yetersiz ve eksik gördüklerini belirtmişlerdir. Bu araçların özet bilgi verdiğini ifade ettiklerini ve meraklarını gideremediklerini ifade etmişlerdir. Turistlerin daha ayrıntılı bilgiye ihtiyaç duyduklarını ve gezi sonunda yönelttikleri sorulara kendileri tarafından cevap verildiğini dile getirmiş̧lerdir. Ayrıca dil anlatımı konusunda sıkıntı yaşadıklarını, hızlı ve kolay alışılabilen bir teknoloji olmadığının turistler tarafından iletildiğini ifade etmişlerdir. Buna karşın, rehberlik mesleği açısından audioguide teknolojisini 3 turist rehberi, turistlerin teknolojik araçlara meyilli olmasından dolayı olumsuz olarak ifade etmemişlerdir. İki turist rehberi ise bu teknolojinin turistlerce hoş karşılandığını belirtmiştir.

\section{Audio-Guide Teknolojisinin Rehber-Turist İletişimi Üzerine Etkileri}

Turist rehberlerinin 18'i audio-guide teknolojisinin zorunlu değil, isteğe bağlı olmasını gerektiğini ifade ederken, turist ve rehber ilişkisini azalttığını, iletişim eksikliği yarattığını ifade etmişlerdir. Turist rehberleri audio-guide teknolojisinin tarih ve turizm alanında önemli kabul edilen yerlere yapılan turlarda yer almaması gerektiğini belirtmişlerdir. Turistlerin audio-guide teknolojisi nedeniyle tur sırasında soru sorabilme şansını yakalayamadıklarını ifade etmişlerdir. Turistlerin rahatça rehbere soru soramadığını, aklına takılan ya da merak ettiklerine o an yanıt alamamalarının gezinin ahengini etkilediğini ve tek başına yapılan bir geziden farkı olmadığını ifade etmişlerdir. Ayrıca bir turist rehberi, Uzakdoğulu turistlerin teknolojiye sıcak baktıklarını fakat diğer turist gruplarının gerçek rehber isteğinde ısrarcı olduklarını ifade etmiştir.

\section{Dolmabahçe Sarayı'nda Etkin Bir Gezi Yapılabilmesine Dönük Görüşler}

Turist rehberlerinin büyük bir çoğunluğu öncelikle bu teknolojinin zorunlu olma durumundan çıkarılması gerektiğini ifade etmişlerdir. Eğer bu teknoloji zorunluluğu devam edilecekse bile audio-guide araçlarının rehber zimmeti zorunluluğundan çıkarılması gerektiğini belirtmişlerdir. 
Dolmabahçe Sarayı'nda daha etkin bir gezinin öncelikle gişe sayılarının arttırılması, zorunlu audio-guide araçlarının sayısının arttırılması ile sağlanması gerektiğini ifade etmişlerdir. Audioguide dağıtımının gruplar için ayrı ve birden fazla gişeden yapılması gerektiğini, bunun için ayrı bir ekip kurulması gerektiğini, dağıtım ve toplama işlemelerinin bu gişelerden yapılması gerektiğini ifade etmişlerdir. Rehberlere grubu ile birlikte giriş önceliği sağlanması gerektiği, münferit müşterilerden ayrı bir yerde işlemlerin sürdürülmesinin zaman kaybını ortadan kaldıracağı belirtilmiştir. Ayrıca görevli personellerin nitelik ve nicelik yönünden yetersiz olduğu, saray içerisinde personel sayısının ve nitelikli personellerin arttırılması gerektiğini ve böylece hizmet kalitesinin artacağı belirtilmiştir. Dolmabahçe Sarayı'na giriş kısmında işleyiş ve düzenin yetersiz olduğu, bu konuda önlemler alınması gerektiği az da olsa rehber ifadeleri arasında yer almaktadır. Bireysel turist gezileri ve rehber-turist gezilerinin birbirinden ayrılarak, haftanın belirli günlerine sabitlenerek, daha etkin ve aktif bir gezi sağlanabileceği ifade edilmiştir.

\section{SONUÇ ve ÖNERILER}

Turist rehberlerinin, büyük bir çoğunluğunun Dolmabahçe Sarayı'nda uygulanan audio-guide teknolojisine karşı olumsuz bir bakış açısına sahip oldukları çalışmada belirlenmiştir. Turist rehberleri audio-guide teknolojisinin rehberin asli görevini ihlal ederek "bilgilendirme" yaptığını, bu teknolojiyi meslek adına tehdit olarak gördüklerini ifade etmişlerdir. Turist rehberleri, Dolmabahçe Sarayı'nda uygulanan audio-guide teknolojisinin; bilgi konusunda yetersiz olduğunu, rehberin grupla ilişkisini olumsuz etkilediğini ve sınırlandırdığını, turistlerce kolay anlaşılamadığı ve dil anlatımı konusunda problemler olduğunu, turistlerin audio-guide teknolojisi ile sorularına cevap alamadıkları ve merakların tam anlamıla gideremediklerini belirtmişlerdir. Ayrıca turist rehberleri audio-guide teknolojisinin müze ve ören yerlerine girerken alım ve geri dağıtımında sorunlar yaşandığını ve turistlerde memnuniyet düzeyinin azaldığını ifade etmişlerdir.

Dolmabahçe Sarayı'nda etkin bir gezi için turist rehberleri audio-guide uygulamasının zorunluluğunun kaldırılması gerektiğini, zorunluluk kalkmayacak ise turist rehberlerine zimmet edilme zorunluluğunun kaldırılması gerektiğini, gişe ve audio-guide sayısının artırılmasının gerektiğini belirtmişlerdir. Turist rehberleri müzede etkin bir tur için audio-guide gişelerinin ayrı olması, audio-guide için özel bir ekip kurulmasının yararlı olacağını ifade etmişlerdir. Rehberli gruplara öncelik tanınmasının veya belirli günlerde bireysel ve grup alımı şeklinde müzenin ziyaretçi almasının daha uygun olacağını ifade etmişlerdir. Müze ziyaretleri sırasında işleyiş ve düzenin gerektiği gibi olması için çalışan sayılarının arttırılması ve nitelik açısından ise daha donanımlı olmalarına özen gösterilmesi gerektiğini ifade etmişlerdir.

$\mathrm{Bu}$ çalışmada, turist rehberlerinin, audio-guide teknolojisine karşı olumsuz olsa da tamamen karşı olmadığı belirlenmiştir. Audio-guide teknolojisinin belli yerlerde bireysel turistlerin kullanımıyla sınırlanması gerektiği belirlenmiş̧tir. Turist rehberliği hizmetini engelleyen bir uygulama olarak değil aksine destek aracı olarak kullanılması gerektiği sonucuna varılmıştır. Etkin bir tur için tarihi ve turistik açıdan önemli kabul edilen Dolmabahçe Sarayı gibi mekânlarda turist rehberlerinin anlatımının tura anlam kazandıracağı ve daha verimli olacağı ifade edilmiştir.

Bu çalışma müze, ören yerlerinde tarihi ve turistik mekânlar da kullanılan audio-guide teknolojisi ile ilgili bilgi vermiştir. Turist rehberlerinin Dolmabahçe Sarayı'nda kullanılan audio-guide teknolojisi hakkında düşünceleri ortaya konularak, audio-guide teknolojisinin turu, turistleri, turist-rehber ilişkisini nasıl etkilediği açılanmıştır. Turist rehberlerinin gözüyle etkin bir gezi için Dolmabahçe Sarayı'nda ve diğer müzelerde neler yapılması gerektiğiyle ilgili önerilerde bulunarak alan yazınına katkı sağlanmak istenmiştir. 
Alınyazında audio-guide teknolojisini rehberlerin gözüyle inceleyen bir çalışmaya rastlanmamıştır. Ancak Çakmak ve Demirkol (2017) teknolojik gelişmelerin turist rehberliği mesleğine etkisini değerlendirdiği çalışmada, teknolojinin turizm sektöründe ve rehberlik mesleğinin icra edilmesinde de önemli olduğu ve öneminin giderek artacağı sonucuna varmıştır. Ayrıca, teknolojilerin turist rehberlerinin alternatifi olma yolunda da hızla ilerlediği belirtilmiştir. Yıldız (2018) çalışmasında turist rehberlerinin çoğunun, teknolojik rehber olarak kullanılan uygulamaların turist rehberi ihtiyacını azaltıcı bir yönde etkisi olacağını belirtmiştir. Ayrıca çalışmada turist rehberleri, teknolojik rehber olarak nitelenen araçların performansının yetersiz olduğunu belirtmişlerdir. Çünkü, turist rehberliği mesleğinin sadece bilgi vermek ve refakat etmek ile sınırlı olmadığını; bu unsurların yanında problem çözebilme, hızlı karar alabilme yetilerine; duygusal ve psikolojik insani vasıflara sahip olması gerektiğini ifade etmiştir. Eser vd., (2019) çalı̧̧masında turist rehberlerinin, audio-guide teknolojisinin müze ve ören yerlerinde kullanımının gereksiz olarak gördüklerini, programlanmış makinelerden farklı bir uygulama olmadıklarını belirttiklerini ifade etmiştir. Çalışmada ayrıca rehberlik mesleğinin önünde bir tehdit olarak görülen audio-guide teknolojisinin belli koşullara bağlanması gerektiği belirtilmiştir.

Çalışma kapsamında, turist rehberlerine ve yetkili kurum ve kuruluşlara bazı öneriler geliştirmiştir:

- Kültür ve Turizm Bakanlığının, rehberlik mesleğinin önünde bir engel olarak görülen bu teknolojileri belli noktalarda denetim altına alması ve sınırlandırması gerekmektedir.

- Müzelerde etkin bir gezi için nitelikli personel yetiştirilmeli, alınmalı ve müzelerin işleyişi bakımından denetimi sağlanmalıdır.

- Turist rehberlerinin audio-guide teknolojisi zorunlu dahi olsa turistler ile ilişkileri sınırlandırmamak adına müze ziyaretleri birlikte yapmalı, ziyaret kontrol altında tutmalıdır.

- Audio-guide teknolojisi devam ettiği takdirde; teknolojinin bilgi eksikliği varsa giderilmeli, sürekli güncellenmeli ve dil anlatım açısından kolay hale getirilmelidir.

- Audio-guide teknolojisi devam ettiği sürece; müzelerde etkin bir gezi için bu donanımların alındığı gişe sayısı artırılmalı ve gerekirse özel bir ekip kurulmalıdır.

- Audio-guide teknolojisinin kullanımı sürdüğü takdirde; müzelerde kalabalığı engellemek ve turist memnuniyetini artırmak açısından grup halinde gelenlere öncelik tanınmalı, gerekli durumlarda belirli günler gruplara ziyarete açılmalıdır.

Çalışmanın çeşitli sınırlılıkları şunlardır. Çalışmaya aktif 23 turist rehberi katılmıştır. Görüşmeler kabul edilebilir bir sayıdadır. Bunun sebebi zaman kısıtlamasıdır. İlerde yapılacak çalışmalarda audio-guide teknolojisinin etkileri birçok farklı müzede ve zamanda yapılabilir. Ayrıca ileriki çalışmalarda turistlerde çalışmalara dahil edilerek audio-guide kullanımı derinlemesine incelenebilir.

\section{KAYNAKÇA}

Ahipaşaoğlu, S. (2006). Turizmde Rehberlik. (2.Basım), Ankara: Gazi Yayınevi.

Buhalis, D. and Law, R. (2008). Progress in Information Technology and Tourism Management: 20 years on and 10 years after the Internet-The State of eTourism research, Tourism Management, 29(4): 609-623. 
Büyükşalvarcı, A., Altınışık, İ. ve Tekin, Ö. (2017). İnteraktif Teknolojilerin Turist Rehberliği Eğitiminde Kullanımı, Selçuk Üniversitesi Sosyal ve Teknik Araştırmalar Dergisi, 13: 1-14.

Bjorneseth, B. F. (2005). Mobile Tourist Guide, Unpublished Master's Thesis, Starathclyde University, Glasgow, Scotland.

Ceserio, V., Coelho, A. and Nisi, V. (2017). Audio-Guides and Human Tour Guides: Measuring Children's Engagement and Learning at A Museum Setting, Conference: Chitaly 2017, Volume:1910, Cagliary, Italy.

Collins, G. R. and Cobanoglu, C. (2008). Hospitality Information Technology: Learning How to Use It, (6th ed.), IA: Kendall/Hunt, Dubuque.

Çakmak, T. F. ve Demirkol, Ş. (2017). Teknolojik Gelişmelerin Turist Rehberliği Mesleğine Etkileri Üzerine Bir Değerlendirme, Bingöl Üniversitesi Sosyal Bilimler Enstitüsü Dergisi, 7(7): 221-235.

Çapar, G. ve Karamustafa, K. (2018). Turist Rehberliği ve Teknoloji, (Editör) Eser, S., Şahin, S. ve Çakıcı, A. C. : Turist Rehberliği içinde (ss.205 -220) Ankara: Detay Yayıncılık.

Çolakoğlu, O. E., Efendi, E. ve Epik, F. (2017). Tur Yönetimi ve Turist Rehberliği. (4.Basım), Ankara: Detay Yayıncilik.

Devices, W. (2015). The Use of Smart Technology in Tourism: Evidence From, Journal of Tourism and Hospitality Management, 3(12): 224-234.

Durna, U. ve Babür, S. (2011). Otel İşletmelerinde Yenilik Uygulamaları, Uluslararası Alanya İsletme Fakültesi Dergisi, 3(1): 73-98.

Eser, S., Çakıcı, C., Babat, D. ve Kızılırmak, İ. (2019). Turlarda Teknoloji Kullanımı Turist Rehberleri Gözüyle Değerlendirme, 7.Ulusal 3.Uluslararası Doğu Akdeniz Turizm Sempozyumu, İskenderun Teknik Üniversitesi. İskenderun.

Eser, S. (2018). Meslek Olarak Turist Rehberliği, (Editör) Eser, S., Şahin, S. ve Çakıcı, A. C. : Turist Rehberliği içinde (ss.25-46) Ankara: Detay Yayıncılık.

Harmankaya, M. B. (2010). Müzelerde Elektronik Rehberlik Uygulamaları, Uzmanlık Tezi, T.C. Kültür ve Turizm Bakanlığı, Kültür Varlıkları ve Müzeler Genel Müdürlüğü, İstanbul.

http://dosim.kulturturizm.gov.tr/sesli rehberlik-projesi [Erişim Tarihi: 20.10.2019].

http://iro.org.tr/tr/226-page-dolmabahce-ve-beylerbeyi-saraylarinda-headsetuygulamasi.aspx [Erişim Tarihi: 20.09.2019].

https://www.millisaraylar.gov.tr/hizmetler/gezi-yonetmeligi [Erişim Tarihi: 20.09.2019].

Khatri, I. (2019). Information Technology in Tourism \& Hospitality Industry: A Review of Ten Years' Publications, Journal of Tourism \& Hospitality Education, 9: 74-87.

Köroğlu, Ö. (2013). Turist Rehberlerinin İş Yaşamındaki Rolleri Üzerine Bir Değerlendirme, Pamukkale Üniversitesi Sosyal Bilimler Enstitüsü Dergisi, 16: 91-112.

Sarsılmaz, Y. (2010). Müzelerde Teknoloji Kullanımı, İstanbul Aydın Üniversitesi Sosyal Bilimler Dergisi, 20: 45-53.

Martins, C. (2012). The Museum (Audio) Guide as an Accessibility Enhancer, (Editör) C. A. Morales, C. Limbach and M.O. Luque: Accesibilidad en la nueva era de Las Comunicaciones Profesionales y universidad: un diálogo imprescindible in (ss.101-115) Granada: Ediciones Tragacanto Publisher. 
Mason, M. (2010). Sample Size and Saturation in PhD Studies Using Qualitative Interviews, FQS Forum: Qualitative Social Research, 11(3): 1-19.

Özel, N. (2016). Müzelerde Bilginin Düzenlenmesi ve Erişime Sunulması: Ankara'daki Müzelere Yönelik Bir Araştırma, Ankara Üniversitesi Dil ve Tarih-Coğrafya Fakültesi Dergisi, 56(1): 177-209.

Stram R., Vendel M. and Bredican J. (2014). Mobile marketing: A Literature View on Its Value for Consumers and Retailers, Journal of Retailing and Consumer Services, 21(6): 1001-1012.

Tekin, Ö., Bideci, M. ve Avcıkurt, C. (2017). Turist Rehberliğinde Yeni Teknolojiler Kullanımı, (Editör) Güzel, Ö. Altıntaş, V. ve Şahin, İ.: Turist Rehberliği Üzerine Araştırmalar içinde (ss.291-305) Antalya: Akdeniz Üniversitesi.

Ünüvar, Ş. (2008). Turizm Sektöründe Bilgi İletişim Teknolojilerinin Kullanımı, Selçuk Üniversitesi Sosyal Bilimler Meslek Yüksekokulu Dergisi, 10 (2): 597-618.

Wahab, I. N. (2017). Role of Information Technology in Tourism Industry: Impact and Growth, International Journal of Innovative Research in Computer and Communication Engineering, 5(2): 260263.

Yıldız, S. (2018). Profesyonel Turist Rehberlerinin Teknolojik Rehber Algısını Belirlemeye Yönelik Bir Araştırma: İstanbul Örneği, Journal of Socıal and Humanities Scıences Research, 5(31): 4686-4697.

Yolal, M. (2003). Türkiye'deki Küçük ve Orta Büyüklükteki Konaklama İşletmelerinde Bilgi Teknolojileri Kullanımı. Eskişehir: Anadolu Üniversitesi Yayınları.

Yüksek, G. (2013). Seyahat İşletmelerinde Bilgi Teknolojilerinin Rolü ve Küresel Dağıtım Sistemlerine Bir Örnek: Amadeus, Online Academic Journal of Information Technology, 4(12): 18-28. 